\title{
Analisis Wacana Kritis Pemberitaan Kasus Suap Soemarmo RAPBD 2012 Kota Semarang di Surat Kabar Harian Suara Merdeka
}

\author{
Ratna Riadhini Darmawan \\ (ratnariadhinidarmawan51@gmail.com)
}

\begin{abstract}
This research aim to understand the text, the discourse practice, and the sociocultural practice which Suara Merdeka showed in their publications about bribery case of Semarang's RAPBD 2012 which claims Soemarmo.

The theoritical of this study required critical paradigm. Stuart Hall in Eriyanto (2008) wrote that mass media is not produce a news, but they determine reality through words.

The research method used critical discourse analysis by Norman Fairclough. Three steps analysis by Faircough are text analysis, discourse practice analysis, and sociocultural analysis. The texts have been analyzed by linguistic, grammar and vocabulary. Discourse practice analysis related to production and consumtion process. Sociocultural analysis related to outside elements of the texts. The researcher collected data by text analyzed and interviewed a journalist and the editor in chief of Suara Merdeka. The study has been done in Semarang.

This research found that Suara Merdeka wrote the text about this case very carefully. There was a special agenda setting to write about it. The socioculture practice analysis showed that the capitalist has intervented the editorial.
\end{abstract}

Kata Kunci : Analisis Wacana Kritis, Kasus Suap, Suara Merdeka

\section{A. Pendahuluan}

Warga kota Semarang pasti mengenal sosok Soemarmo Hadi Saputro. Jabatan terakhirnya adalah Wali Kota Semarang terpilih periode 2010-2015. Sayangnya, pada tanggal 13 Mei 2013 yang lalu Menteri Dalam Negeri resmi memberhentikan tugasnya sebagai orang nomor satu di Semarang. Hal ini berkaitan dengan kasus suap APBD Kota Semarang yang menjadikannya sebagai tersangka.

Sementara itu, dalam hal informasi terkait kasus suap yang menimpa wali kotanya, warga Semarang mengandalkan berbagai media mulai dari media cetak, elektonik hingga portal online terutama media lokal seperti Suara Merdeka, Radar Semarang, hingga Kompas.

Pada tanggal 19 Maret 2012, Suara Merdeka memuat tajuk rencana yang berjudul 'Tragedi dalam Resiko Relasi Kekuasaan'. Tajuk rencana merupakan opini institusi media massa terkait sebuah issu dalam masyarakat. Melalui tulisan-tulisannya, media massa berperan besar dalam pembentukan opini publik. Sebuah peristiwa dapat diberitakan secara berbeda tergantung bagaimana media menuliskan realitas yang ada. Dari beberapa judul berita yang ditulis Suara Merdeka dan tajuk rencana seperti diatas, tampak kecenderungan Suara Merdeka berpihak kepada Soemarmo. Fenomena ini menarik untuk diteliti lebih lanjut bagaimana dan ada apa dibalik media terbesar di Jawa Tengah ini memilih bahasa dan menuliskan berita terkait kasus suap Soemarmo tersebut kepada masyarakat.

Konsumen media perlu mengetahui bahwa penulisan berita 
dipengaruhi oleh beberapa faktor baik dari internal maupun eksternal media. Pengungkapan faktor-faktor yang mempengaruhi menulisan berita dapat dilakukan dengan menggunakan analisis wacana.

\section{B. Tinjauan Pustaka \\ 1. Paradigma Kritis dalam Penelitian Kasus Suap Soemarmo di Koran Suara Merdeka}

Titik penting dalam memahami media menurut paradigma kritis adalah bagaimana media melakukan politik pemaknaan. Mengutip Stuart Hall dalam Eriyanto (2008: 37) media massa pada dasarnya tidak memproduksi, melainkan menentukan realitas melalui pemakaian kata-kata yang terpilih.

Pertanyaan utama dari paradigma kritis adalah adanya kekuatan-kekuatan yang berbeda dalam masyarakat yang mengkontrol proses komunikasi (Eriyanto, 2008: 23). Penelitian yang dilaksanakan berdasarkan paradigma kritis ini diarahkan dalam rangka membongkar kenyataan palsu yang telah diselewengkan dan dipalsukan tersebut leh kelompok dominan untuk kepentingannya (Eriyanto, 2008: 26). Media sebagai kekuatan besar yang berperan dalam memanipulasi kesadaran dan kenyataan. Berdasarkan paradigma kritis, bagaimana berita tentang kasus suap Soemarmo dihadirkan oleh Suara Merdeka kepada pembacanya akan diteliti melalui pendekatan analisis wacana kritis.

\section{Analisis Wacana Kritis Norman Fairclough}

Analisis wacana kritis adalah sebuah proses penguraian sebuah teks sebagai upaya pengungkapan maksud tersembunyi dari subjek (penulis) yang mengemukaan suatu pernyataan. Pengungkapan dilakukan dengan menempatkan diri pada posisi penulis dengan mengikuti struktur makna dari sang penulis sehingga bentuk distribusi dan produksi ideologi yang disamarkan dalam wacana dapat diketahui (Yoce, 2013: 49).

Dalam Eriyanto (2008) dijelaskan bahwa Fairclough membagi analisis wacana dalam tiga dimensi: text, discourse practice dan sociocultural practice. Teks dianalisis secara linguistik, dengan melihat kosakata, semantik, dan tata kalimat. Melalui analisis linguistik dapat dilihat muatan ideologi tertentu, kontruksi hubungan wartawan dan pembaca serta identitas yang hendak ditampilkan.

Discourse practise merupakan dimensi yang berhubungan dengan proses produksi dan konsumsi teks. Informasi di media dibentuk oleh bermacam-macam faktor. Produksi teks berita antara lain dipengaruhi oleh ideologi dan perasaan wartawan serta kebijakan redaksional. Sedangkan proses konsumsi teks bisa jadi berbeda dalam konteks sosial yang berbeda pula. Konsumsi teks bisa dihasilkan secara personal ataupun secara kolektif.

Sociocultural practice adalah dimensi yang berhubungan dengan konteks di luar teks. Yang termasuk konteks sosial di sini antara lain, seperti situasi ketika berita itu dibuat, serta praktik institusi dari media sendiri dalam hubungannya dengan masyarakat atau budaya dan politik tertentu.

\section{Mediating The Message, Shoemaker dan Reese}

Analisis wacana kritis menjadikan isi media sebagai bahan kajiannya. Apa yang disajikan media pada dasarnya adalah akumulasi dari pengaruh yang beragam. Berita yang ditampilkan media sudah melalui berbagai proses sehingga hasilnya tidak utuh lagi seperti fakta. Pamela J. Shoemaker dan 
Stephen D. Reese dalam Mediating The Message: Theories of Influence on Mass Media Content (1996: 64), menyusun berbagai faktor yang mempengaruhi pengambilan keputusan dalam ruang pemberitaan. Faktr-faktr tersebut antara lain: level individual wartawan, rutinitas media, organisasi media, ekstra media, dan ideologi media.

\section{Metodologi Penelitian \\ 1. Lokasi Penelitian}

Penelitian ini akan dilakukan di Semarang. Hal ini dikarenakan letak kantor redaksi surat kabar Harian Suara Merdeka ada di kota Semarang.

\section{Bentuk dan Strategi Penelitian}

Penelitian ini mengarah pada analisis teks pada surat kabar harian Suara Merdeka sehingga bentuk penelitian yang tepat untuk penelitian ini adalah penelitian kualitatif deskriptif. Dengan metode deskriptif, informasi yang didapatkan lebih detail dan mendalam.

Pendekatan penelitian yang digunakan dalam penelitian ini adalah pendekatan kritis. Pandangan ini menekankan nilai atau kritikan peristiwa, situasi dan isntitusi.

\section{Data dan Sumber Data}

Sumber data dari penelitian ini adalah artikel berita terkait kasus suap Soemarmo pada surat kabar harian Suara Merdeka. Sedangkan nara sumber dari penelitian ini adalah wartawan yang menulis berita terkait kasus suap Soemarmo dan redaktur surat kabar harian Suara Merdeka.

\section{Teknik Cuplikan (Sampling)}

Teknik cuplikan yang digunakan dalam penelitian ini adalah teknik cuplikan yang bersifat selektif. Peneliti akan memilih artikel yang menarik dan informan yang dianggap memiliki intensitas lebih dalam proses produksi berita terkait kasus suap Soemarmo di surat kabar harian Suara Merdeka. Adapun cuplikan artikel yang akan diteliti adalah artikel berita terkait kasus suap Soemarmo pada rentang bulan November 2011- Agustus 2013.

\section{Teknik pengumpulan data}

a. Analisis Teks

Mengumpulkan beberapa artikel berita terkait kasus suap Soemarmo di surat kabar harian Suara Merdeka.

b. Wawancara

Salah satu pembagian wawancara oleh Patton (dalam Maleong, 2006: 187) adalah wawancara dengan pendekatan menggunakan petunjuk umum wawancara.

6. Validitas Data

Pengembangan validitas penelitian ini menggunakan model triangglasi data. Cara trianggulasi data dilakukan dengan melakukan konfirmasi, baik konfirmasi teori maupun konfirmasi kepada sumber.

7. Teknik Analisis Data

Tahapan analisis yang pertama, teks, adalah tahapan deskripsi yakni menguraikan isi dan analisis secara deskriptif atas teks. Pada tahap ini teks dijelaskan tanpa dihubungkan dengan aspek lain. Pada tahapan analisis yang kedua, discourse practice, analisis melakukan interpretasi atau menafsirkan teks dihubungkan dengan praktik wacana yang dilakukan. Tahapan yang terakhir, yaitu sociocultural practice, bertujuan mencari penjelasan atau eksplanasi atas hasil penafsiran kita pada tahap kedua. Penjelasan itu dapat diperoleh dengan mencoba menghubungkan produksi teks itu dengan praktik sosiokultural di mana suatu media berada (Eriyanto, 2001: 327).

D. Hasil dan Pembahasan

1. Wacana dalam Media Massa 
Media massa selama ini digunakan oleh masyarakat sebagai tempat memperoleh informasi, lebih dari itu sesungguhnya media massa mencoba membangun suatu nilai dalam pikiran dan benak khlayaknya. Sayangnya tidak banyak khalayak media massa yang menyadari bahwa realitas yang ditampilkan oleh media massa sesungguhnya bukanlah realitas yang sebenar-benarnya. Media massa menyuguhkan second hand reality, informasi yang ada di dalam media massa tersebut dibentuk oleh bermacam-macam faktor antara lain ideologi wartawan sebagai penulis berita dan faktor redaksional.

Media massa sebagai bentuk industri bisnis juga dikontrol ketat oleh pemilik modal (pengusaha). Oleh karena itu, media massa bukanlah alat yang pasif melainkan aktif karena memiliki kepentingan tersendiri yang disebut "politik redaksi". Wacana media merupakan kelanjutan dari praktik agenda setting media memiliki pengaruh terhadap pencitraan atau gambaran realitas yang melekat di benak khalayak.

2. Kasus suap RAPBD 2012 Kota Semarang yang Melibatkan Soemarmo

Kasus suap yang membelit Soemarmo merupakan kasus suap RAPBD Semarang tahun 2012 yang terbongkar saat Komisi Pemberantasan Korupsi (KPK) menangkap tangan dua anggota DPRD Kota Semarang, Sumartono dan Agung Purno Sarjono, serta sekretaris daerah Kota Semarang, Zaenuri, di halaman parkir gedung DPRD Kota Semarang pada 24 November 2011 pukul 11.30 wib. Di tempat tersebut tim dari KPK juga menemukan amplop putih berisi uang sejumlah Rp 40 juta yang sedianya akan dibagikan kepada para anggota DPRD Kota Semarang.
3. Suara Merdeka Korannya Jawa Tengah

Suara Merdeka lahir pada 11 Februari 1950 dan merupakan salah satu koran tertua yang ada di Indonesia. Suara Merdeka didirikan oleh $\mathrm{H}$. Hetami dengan misi awal memperdengarkan suara rakyat yang baru saja merdeka.

Saat ini, Suara Merdeka dipimpin oleh generasi ketiga. Hetami menyerahkan kepemimpinannya pada menantunya Ir. Budi Santoso pada tahun 1982 selama dua belas tahun. Pada tahun 2010 hingga sekarang Kukrit Suryo Wicaksono, yang merupakan putra dari Ir. Budi Santoso, memegang tongkat estafet kepemimpinan koran ini. Kukrit selain menjadi CEO Suara Merdeka saat ini aktif sebagai ketua Kadin Jawa Tengah serta mengelola beberapa perusahaan seperti Hotel Oak Tree Semarang.

4. Analisis Teks Menurut Fairclough

a. Representasi teks

Tajuk rencana ini menuliskan satu kalimat aktif, yang menunjukkan Soemarmo sebagai subjek dalam kalimat: "Wali Kota memilih menempuh peminimalan resiko politik yang ternyata keliru, dan mendatangkan tragedi kekuasaan". Keliru dalam Kamus Besar Bahasa Indonesia berarti salah atau khilaf (1989: 411). Sementara itu, jika dirunut lebih jauh, 'khilaf' sendiri berarti salah yang tidak disengaja (KBBI, 1989: 437). Kalimat ini dapat direpresentasikan bahwa Soemarmo yang tidak sengaja memilih langkah akhirnya terlibat dan menjadi korban kasus suap RAPBD 2012. Sebelumnya, langkah yang diambil oleh Soemarmo saat itu bisa dikatakan sebagai langkah yang benar dan wajar dilakukan.

b. Discourse Practice 
Amir menjelaskan dalam penulisan berita terkait kasus suap RAPBD 2012 yang melibatkan Soemarmo, redaksi memberikan instruksi kepada wartawan antara lain, pertama, wartawan menulis fakta-fakta sesuai yang ditemukan di lapangan tetapi tidak mengembangkannya dengan opini, tidak perlu mencari pendapat yang memberatkan, cukup polosan saja dan fakta-fakta hukumnya saja yang diangkat. Kedua, redaksi memberi arahan sesuai agenda setting, namun menurut Amir hal itu jarang dilakukan. Yang terpenting menurutnya, Eka (wartawan) cukup membuat naskah nanti yang akan menghaluskan dan memformat adalah redaksi. Naskah diubah, dihaluskan namun tidak meninggalkan substansi berita.

\section{c. Sociocultural Practice}

Pemberitaan kasus suap RABPBD 2012 yang melibatkan Soemarmo di koran Suara Merdeka diakui oleh Pemimpin Redaksi, Amir Machmud telah diintervensi oleh kepentingan pemilik modal. CEO Suara Merdeka Grup memiliki hubungan baik dengan Soemarmo.

\section{E. Kesimpulan}

Hasil penelitian tentang pemberitaan seputar kasus suap RAPBD 2012 yang melibatkan Soemarmo di koran Suara Merdeka dengan metode analisis wacana kritis Norman Fairclough didapatkan hasil sebagai berikut:

Pertama, Suara Merdeka menuliskannya dengan sangat hati-hati. Kata-kata yang dipilih menggunakan pilihan kata berkonotasi positif, dengan bahasa yang humanis. Penyusunan kalimatnya menunjukkan Soemarmo sebagai subjek yang terkena tindakan.

Kedua, hasil wawancara dengan wartawan dan pemimpin redaksi Suara Merdeka pada tahap analisis discourse practice menunjukkan bahwa ada agenda setting khusus dalam pemberitaan kasus suap RAPBD 2012 yang melibatkan Soemarmo. Sikap yang diambil Suara Merdeka pada kasus ini adalah tidak memformat berita kasus suap RAPBD 2012 sebagai headline, namun Suara Merdeka tetap menerbitkan berita kasus tersebut dengan pertimbangan agar tidak tertinggal dengan media-media lain.

Ketiga, analisis sociocultural practice menunjukkan bahwa ada intervensi dari pemilik modal dalam penerbitan berita terkait kasus suap RAPBD 2012 yang melibatkan Soemarmo. Kedekatan antara pemilik modal dengan Soemarmo diakui oleh staf redaksi Suara Merdeka sebagai hal yang mempengaruhi isi pemberitaan terkait Soemarmo di koran Suara Merdeka.

Berdasarkan hasil analisis wacana kritis di atas, maka dapat disimpulkan bahwa penulisan berita terkait kasus suap RAPBD 2012 yang melibatkan Soemarmo di koran Suara Merdeka tidak fair dan cenderung parsial, menunjukkan sikap memihak terhadap Soemarmo.

\section{F. Daftar Pustaka}

Eriyanto. 2008. Analisis Wacana: Pengantar Analisis Teks Media. Yogyakarta: Lkis

Lexi J Maleong. 2006. Metode Penelitian Kualitatif. Bandung: PT. Remaja Rosdakarya

Shoemaker and Reese. 1996. Mediating The Message: Theories of Influences on Mass Media Content, Second Edition. USA: Longman

Yoce Aliyah Darma. 2013. Analisis Wacana Kritis. Bandung. Yrama Widy 
